\title{
Review: Prostitution and Sex Work in Global Cinema: New Takes on Fallen Women, edited by Danielle Hipkins and Kate Taylor-Jones
}

Dina Iordanova

https://doi.org/10.15664/fcj.v0i17.2057

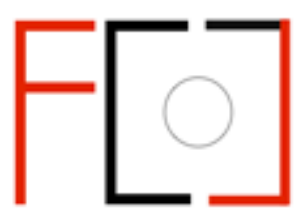

Frames Cinema Journal

ISSN 2053-8812

Issue 17 (Jun 2020)

http://www.framescinemajournal.com

(c) $\underset{\mathrm{EY}}{(\mathrm{P}}$ 


\section{Prostitution and Sex Work in Global Cinema: New Takes on Fallen Women Edited by Danielle Hipkins and Kate Taylor-Jones \\ Palgrave Macmillan, 2017 \\ Reviewed by Dina Iordanova, University of St Andrews}

Back in 2006, Wisconsin Film Studies published Russell Campbell's Marked Women: Prostitutes and Prostitution in the Cinema. ${ }^{1}$ The book, mainly focused on cinematic material derived from American cinema, provided an extended typology of the treatment of prostitution in film and rapidly became the authoritative study on the subject. And indeed, almost all of the essays included in the collection Prostitution and Sex Work in Global Cinema: New Takes on Fallen Women reference Campbell's work. But this new volume - edited by British scholars Danielle Hipkins (Exeter) and Kate Taylor-Jones (Sheffield) - significantly widens the horizon of the investigation, and in that it is a major contribution to scholarship.

The collection appears as part of Palgrave Macmillan's Global Cinema series, the general editors for which are US-based European scholars Katarzyna Marciniak, Aniko Imre and Aine O'Healy. It is a series that has permitted teams of scholars who are keen to approach matters transnationally to go ahead with original projects, of which this volume on prostitution is a great example. The team has done a formidable job in ensuring that the chapters in the collection provide all-encompassing geographical coverage, discussing films and discourses from South Korea, Japan, Hong Kong, India, Australia, Canada, France, Italy, Sweden, Britain, Romania, Moldova, Mexico, and Nigeria. Indeed, its geographical reach is extended even further by the fact that the protagonists of these films are often migrants who have crossed borders, from Russia into Sweden, from Turkey into Germany, or from Tunisia into Italy. The team of authors - mainly based at institutions in the UK and the USA - is equally diverse, both in their origins and their fields of expertise; they range from academics working in language and literature departments to cultural studies and media specialists.

The volume has evidently been in the making for some years, as the preface mentions a 2010 conference at the University of Exeter on the same topic. It is a well thought through and mature project, properly framed by an introduction and a conclusion that elaborate the choices of films and the clustering of chapters. In the first part, Jane Arthurs and Alice Bardan's contributions deal with contemporary films about trafficking and border crossing in post-Cold War Europe. The next part includes texts by Adam Bingham (on 1950s Japan), Molly Hyo Kim (on 1970s South Korea) and Shaheed Aderinto (on Nigerian representations from the $21^{\text {st }}$ century), which consider films that all revolve around prostitution as part of "the cinematic city" and the dynamics of urban social stratification. The third part, entitled "Transgressive Women?", includes two solidly argued studies: Niamh Thornton writes about several films of the Mexican star Maria Felix, spanning the period between the mid-1940s and 1961; and Teresa Ludden discusses the representation of prostitution in German films from the 1970s. (I was particularly pleased to see a discussion of Helma Sanders-Brahms' Shirin's Wedding (1976), a lesser-known yet hugely important early text on migration, class, ethnicity and traditional patriarchy. $\left.{ }^{2}\right)$ The fourth part contains three chapters exploring "the suffering heroine" - a morally and emotionally conflicted "fallen woman", who manifests again and again over time and in different cultural and linguistic contexts. All texts in this part - by Aparna Sharma on Pakeezah (India, 1971), by Danielle Hipkins and Katharine Mitchell on Francesca Comencini's Un giorno speciale (Italy, 2012), and by Katie N. Johnson on Baz Luhrman's take on Moulin Rouge! (2001) - traverse wide territories and historical contexts to 
provide continuity in the exploration of the tragic figure of the prostitute. And, last but not least, the fifth part revisits "fallen women" in the post-modern city, focusing on Toronto-set Chloe (2009) and a range of films featuring the lives of prostitutes in large East Asian cities (Hong Kong, Seoul, Tokyo). I was particularly fascinated by the essay on Chloe. ${ }^{3}$ It elegantly exposes the subtle sinking of Canadian auteur Atom Egoyan into this lucrative mainstream erotic thriller, engineered by tireless Canadian-Hollywood father-son producer duo Ivan and Jason Reitman. The analysis of the promotional card for the film, which tries to push Toronto lifestyle and tourist locations by building on the subtle associations between high-class escorts and modern cityscapes, is excellent. The contributions in this last part (by Fiona Handyside and Kate Taylor-Jones) are particularly to my taste, as they manage to go beyond text and bring into discussion the specifics of urbanism, as well as the production and reception/circulation history of the films.

I want to return, for a moment, to the matter of "issue-based" film studies - a term that I am using to describe a large body of film studies writing that does not rely mainly on the textual analysis toolset but is rather focused on exploring film as a representational tool that fosters social discourse. Issue-based film studies may occasionally engage with matters of narratology, film style and mise-en-scene, but only to the extent that this is related to the main focus of investigation: the socio-cultural phenomenon that these films are concerned with. The typology of prostitution (more than ten categories, ranging from the "happy hooker" to the "avenger") found in Russell Campbell's book is an example of issue-based film studies. It assists in shaping a discourse that relates to a body of films and that can be applied to even more examples, which may display a great array of film styles and may be made in many different languages. In the instance of Prostitution and Sex Work in Global Cinema, the focus of contributions is on the discourse related to prostitution as it transcends cultural borders. On the one hand, the films reflect the specifics of time and place, but on the other, they also influence the way in which prostitution is seen. This is compellingly shown through the analysis of Lilja4Ever (Lukas Moodysson, 2002) in Jane Arthurs' chapter, as well as in Saheed Aderinto's essay on the Nigerian film The Prostitute (Fred Amata, 2001), both of which skilfully plug sociological studies into the analysis.

From this "issue-based" point of view, I admit I had some difficulties with those discussions that reach back to the lives of courtesans from previous centuries to link them to films featuring prostitutes of the present day: as far as I am concerned, society has changed substantially, and the position of the (fallen) woman is more adequately discussed by linking to the given social context rather than to texts from the past. Whereas the principles of chapter clustering are persuasively explained by the editors, I still feel that some chapters, while excellently researched and written as stand-alone pieces, are not particularly relevant in the context of the collection. Still, I believe the volume does an excellent job in outlining and analysing the modern trends in situating prostitution in global cinema. I highly recommend it.

\footnotetext{
${ }^{1}$ Wisconsin is Campbell's alma mater, even if he then returned to his native New Zealand and spent his career teaching at Victoria University in Wellington. In 1971, he founded the film journal The Velvet Light Trap, which is still being published.

${ }^{2}$ Ludden's chapter, however, should have undergone better copy-editing. It was marked by quite a few typos. For some reason, the name of the director appeared as Sanders rather than Sanders-Brahms, an oversight that ought to have been corrected.

${ }^{3}$ Chloe is a remake of the French erotic thriller Nathalie... (2003, Anne Fontaine).
} 